\title{
Time-lapse imaging of subglacial drainage conditions using three-dimensional inversion of borehole electrical resistivity data
}

\author{
Bernd KULESSA, ${ }^{1}$ Bryn HUBBARD, ${ }^{2}$ Giles H. BROWN ${ }^{3}$ \\ ${ }^{1}$ School of the Environment and Society, University of Wales Swansea, Swansea SA2 8PP, UK \\ E-mail: b.kulessa@swansea.ac.uk \\ ${ }^{2}$ Centre for Glaciology, Institute of Geography and Earth Sciences, University of Wales Aberystwyth, Ceredigion SY23 3DB, UK \\ ${ }^{3}$ School of Geographical Sciences, University of Bristol, University Road, Bristol BS8 1SS, UK
}

\begin{abstract}
We recorded electrical resistivity data at the base of four boreholes drilled through Haut Glacier d'Arolla, Switzerland. The data were acquired repetitively every hour over two diurnal hydrological cycles in the late melt season, separated by 10 days. Constrained three-dimensional (3-D) data inversion allowed reconstruction of hourly variations in bulk resistivity in the subglacial sediment layer. Inverted resistivity models reflect the establishment of channelized subglacial drainage in the study area between the two hydrological cycles, in agreement with previous work. Daily variations in bulk and water resistivity are in phase, and bulk resistivity amplitudes decrease away from the subglacial channel. Using selected electrical-hydraulic relationships, we estimate metre-scale changes in the hydraulic conductivity and porosity of the subglacial sediment layer, accounting for increasing clay content and decreasing median grain radius with distance from the channel. Hydraulic conductivity and porosity were respectively calculated to decrease from $(6.4 \pm 2.1) \times 10^{-2} \mathrm{~m} \mathrm{~s}^{-1}$ and $0.34 \pm 0.01$ at the channel to $(3.3 \pm 2.2) \times 10^{-2} \mathrm{~m} \mathrm{~s}^{-1}$ and $0.26 \pm 0.01$ at a distance of $5 \mathrm{~m}$ from it. The hydraulic conductivity estimates are in agreement with previously inferred values, and the porosity estimates fall within the expected range for unlithified subglacial sediments. We conclude that collection and inversion of repeat 3-D subglacial resistivity data is feasible and has the capacity to generate multidimensional images of subglacial hydraulic processes and properties.
\end{abstract}

\section{INTRODUCTION}

This study aims to evaluate whether subglacial electrical resistivity data can be used to produce time-lapse images of hydraulic processes and properties beneath temperate glaciers underlain by unlithified sediments. So far, in situ subglacial drainage conditions have typically been assessed by automated measurements in several individual boreholes drilled, for example, along a one-dimensional (1-D) glacier transect or as a two-dimensional (2-D) array. Subglacial properties of interest could then be interpolated between the boreholes to produce pseudo 1-D profiles or pseudo 2-D images. The feasibility of such approaches has been demonstrated for water pressure, electrical conductivity, turbidity and a host of different basal mechanical and related hydraulic phenomena (e.g. Hubbard and Nienow, 1997; Fischer and Clarke, 2001). One specific advantage of such automated methods is high temporal resolution, limited only by space on the data logger. In contrast, spatial resolution is commonly poor even where many boreholes are densely spaced. This is a particularly important drawback where subglacial hydraulic conditions vary on scales that are smaller than the distance between individual boreholes, as is often the case beneath mountain glaciers (e.g. Murray, 1997). It is therefore desirable to develop techniques that allow spatially complete visualization of subglacial processes and properties at regular time intervals. We believe the use of electrical resistivity methods is particularly promising.

Previous applications of subglacial electrical resistivity measurements range from simple 'electrode tests' for identification of the exact position (Haeberli and Fisch, 1984) or nature (Iken and others, 1996) of the glacier bed, to 1-D electrical soundings for determination of subglacial sediment thickness (Haeberli and Fisch, 1984; Brand and others, 1987), and automated apparent resistivity measurements in support of hydromechanical studies (Blake, 1992; Blake and Clarke, 1999). These investigations are encouraging, but sparse in number, reflecting the need for further subglacial electrical resistivity studies to explore the full potential of this geophysical method. This is particularly true for the use of electrical resistivity data to estimate the hydraulic conductivity and porosity of subglacial sediments. Suitable electrical-hydraulic relationships were developed by Revil and Cathles (1999), which we adopt in the present study. The well-known Kozeny-Carman equation relates the hydraulic conductivity of unlithified, clay-free sediments to their porosity and median grain-size (e.g. Freeze and Cherry, 1979, p. 351). Revil and Cathles (1999) make two significant improvements to this equation: (i) total porosity and total hydraulic radius are replaced with electrical parameters that reflect equivalent effective properties instead, a novel concept that allows for narrow pore throats which exert a major control on hydraulic conductivity; and (ii) the improved variant of the Kozeny-Carman equation is extended for any mixture of sands and clays. This is important in the present context since the subglacial sediments in the study area contained noticeable amounts of clay minerals during the measurement period (Seagren, 1999).

We address three particularly important open questions associated with subglacial electrical resistivity measurements:

1. Is it possible to produce three-dimensional (3-D) timelapse images of changes in subglacial electrical resistivity to support hydrological and hydromechanical studies? 

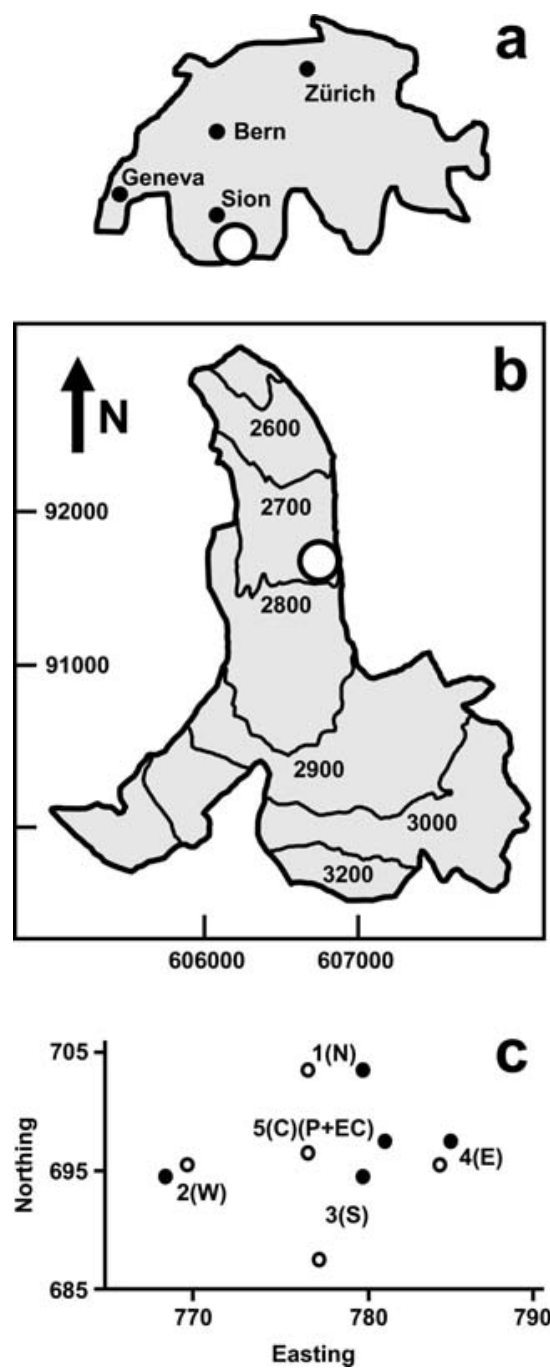

Fig. 1. (a) The location of Haut Glacier d'Arolla in Switzerland (open circle). (b) The location of the study area on the glacier (open circle). (c) The surface (open circles) and base (closed circles) locations of the five boreholes used in this study. Boreholes $1(\mathrm{~N}$, $\mathrm{N}=$ north) through $4(\mathrm{E}, \mathrm{E}=$ east) were used for electrical resistivity measurements, and borehole $5(\mathrm{C}, \mathrm{C}=$ centre) for water-pressure (P) and electrical conductivity (EC) logging. All coordinates in (b) and (c) correspond to the Swiss National Grid, and are abbreviated in (c) for clarity.

2. Is it possible to derive the hydraulic conductivity and porosity of unlithified subglacial sediments with distance from a subglacial channel using borehole-based electrical resistivity measurements?

3. How sensitive are the estimates of hydraulic conductivity and porosity to uncertainties in the parameters that govern the electrical-hydraulic relationships?

\section{FIELD SITE AND METHODS}

\subsection{Field site}

Haut Glacier d'Arolla is a small valley glacier at the head of Val d'Hérens in southwestern Switzerland (Fig. 1a). It has a surface area of $\sim 6 \mathrm{~km}^{2}$ and ranges from $\sim 2600$ to $\sim 3600 \mathrm{~m}$ in elevation (Fig. 1b). The glacier has been subject to extensive multidisciplinary scientific investigations since 1989. Our study area is located in the eastern part of the glacier's ablation zone (Fig. 1b), and spans a major melt-season subglacial channel that reopens ephemerally in July and is particularly active in late summer (August) (e.g. Sharp and others, 1993; Hubbard and others, 1995; Gordon and others, 1998; Kulessa and others, 2003a). The area is known to be at least partially underlain by unlithified sediments whose thickness ranges from $\sim 0.05 \mathrm{~m}$ near the channel to $\sim 0.26 \mathrm{~m}$ several tens of metres away from it (Harbor and others, 1997). The bedrock below the glacier consists mainly of schistose granites and gneisses of the Arolla series (e.g. Mitchell and others, 2001).

\subsection{Borehole array and associated data}

An array of five boreholes (Fig. 1c) was drilled to the glacier bed in early August (day 215) 1996. All boreholes had frozen shut near the glacier surface at the time the measurements were conducted (days 222-223 and 232233). A diamond-shaped array was established to allow measurements both parallel and perpendicular to ice flow, although array shape was distorted with depth due to nonvertical drilling (Fig. 1c). The location of all borehole bases was determined by inclinometry, with an accuracy of better than $0.5 \%$ of ice thickness (Copland and others, 1997). Borehole bases were located at each corner (boreholes 1(N), $2(\mathrm{~W}), 3(\mathrm{~S})$ and $4(\mathrm{E}))$ and in the centre of the diamond (borehole $5(\mathrm{C})$ ). The boreholes connected well with the subglacial water system after drilling, as indicated by fluctuating water levels (Smart, 1996). Borehole 5(C) was used for automated water quality measurements. Solid lead electrodes, soldered to single-conductor cable, were lowered to within $\sim 0.5 \mathrm{~m}$ of the bases of the remaining four boreholes. A further solid lead electrode was buried in an open glass jar $\sim 1 \mathrm{~m}$ deep in the nearby lateral moraine to avoid exposure to surface temperature variations.

Boreholes $1(\mathrm{~N})$ to $4(\mathrm{E})$ were mainly used for automated long-term (August 1996-June 1997) electrical self-potential measurements (Kulessa, 2000; Kulessa and others, 2003a, b), which were twice briefly interrupted to allow use of the electrodes for the electrical resistivity measurements reported here. On the basis of self-potential data collected between the two measurement periods considered here, Kulessa and others (2003a) inferred that channelized water flow occurred along an axis spanned by boreholes $5(\mathrm{C})$ and $1(\mathrm{~N})$ (Fig. 1c). Although the subglacial sediments in our study area contained noticeable amounts of clay minerals during the measurement period (Seagren, 1999), they were largely depleted immediately adjacent to the area of preferential flow as a result of subglacial erosion by hydraulic interaction between this flow and the surrounding sediments (Kulessa and others, 2003a).

\subsection{Electrical resistivity: concepts}

Electrical resistivity measurements allow characterization of the subglacial environment in terms of its ability to conduct electrical current. The electrical resistivity technique commonly involves a series of four-electrode measurements, where two electrodes are used for current injection and two for voltage measurements. Apparent resistivity $\left(\rho_{\mathrm{a}}\right)$ is calculated using

$$
\rho_{\mathrm{a}}=G \frac{\Delta V}{l},
$$

where $G$ is a factor related to the geometrical arrangement of the electrodes, $I$ is injected current, and $\Delta V$ is measured potential difference (e.g. Telford and others, 1990, p. 542). We assume a three-layer system of basal ice, water-saturated 
subglacial sediments and underlying bedrock. The bulk resistivity distribution in this system is determined from $\rho_{\mathrm{a}}$ by geometrically constrained data inversion, and depends strongly on the resistivity of subglacial water because the latter contains the vast majority of mobile ions. This implies that the current will be strongly concentrated in pore water within subglacial sediments, where they are present (Blake, 1992; Blake and Clarke, 1999). We expect this to be the case for our study area at Haut Glacier d'Arolla, where ice resistivity is known to be very large $\left(\sim 10^{8}-10^{9} \Omega \mathrm{m}\right.$; Hubbard and others, 1998) and the resistivity of the crystalline bedrock is also high (several thousand $\Omega \mathrm{m}$; e.g. Telford and others, 1990, p. 290).

Archie's first formula (Archie, 1942; Telford and others, 1990, p. 649) has been used widely to relate bulk resistivity $\left(\rho_{\text {bulk }}\right)$ to water resistivity $\left(\rho_{\text {water }}\right)$ and the electrical formation factor $(F)$ of the unlithified sediment matrix (Equation (2a)). Archie's second formula (Equation (2b)) relates $F$ to the porosity $\left(\phi_{\mathrm{s}}\right)$ and cementation factor $\left(m_{\mathrm{s}}\right)$ of clay-free sediments:

$$
\begin{aligned}
\rho_{\text {bulk }} & =\rho_{\text {water }} F \\
F & =\phi_{\mathrm{s}}^{-m_{\mathrm{s}}} .
\end{aligned}
$$

The improved variant of the Kozeny-Carman equation derived by Revil and Cathles (1999) allows the hydraulic conductivity $\left(K_{\mathrm{s}}\right)$ of clay-free sediments to be estimated from median grain radius ( $R$; equal to half the median grain-size), the formation factor $(F)$ and the cementation factor for clayfree sediments $\left(m_{\mathrm{s}}\right)$ :

$$
K_{\mathrm{s}}=\frac{\delta_{\text {water }} g}{\mu_{\text {water }}} \frac{R^{2}}{2 m_{\mathrm{s}}^{2} F^{3}},
$$

where $\delta_{\text {water }}$ and $\mu_{\text {water }}$ are water density and viscosity respectively, and $g$ is acceleration due to gravity.

The hydraulic conductivity of clayey sediments $\left(K_{\mathrm{cs}}\right)$ is related to $K_{\mathrm{s}}$ by:

$$
K_{\mathrm{cs}}=K_{\mathrm{s}}\left(\frac{\phi_{\mathrm{cs}}}{\phi_{\mathrm{s}}}\right)^{3 m_{\mathrm{cs}}},
$$

where $m_{\mathrm{CS}}$ is the cementation factor for clayey sediments and the porosity of clayey sediments $\left(\phi_{\mathrm{cs}}\right)$ is calculated from

$$
\phi_{\mathrm{cs}}=\phi_{\mathrm{s}}-\varphi_{\mathrm{c}}\left(1-\phi_{\mathrm{c}}\right) \text {, }
$$

where $\varphi_{\mathrm{C}}$ and $\phi_{\mathrm{C}}$ are respectively clay volume fraction and clay porosity (Marion and others, 1992).

\subsection{Electrical resistivity: field measurements}

The electrical resistivity data reported here were collected as repeat measurement frames. A frame is defined as the compilation of all possible direct and reciprocal fourelectrode measurements that resulted from switching between the five available electrodes. Respectively four repeat readings were taken for any particular direct or reciprocal electrode combination. This allowed identification and elimination of unacceptably noisy data prior to inversion (e.g. Binley and others, 1995). Such data were clearly distinguishable from acceptable data points, which commonly had associated errors of $\sim 10 \%$ or less. Measurement frames were repeated every hour between $1300 \mathrm{~h}$ on day 222 and $1800 \mathrm{~h}$ on day 223 (first series; 28 frames in total), and $1300 \mathrm{~h}$ on day 232 and $1300 \mathrm{~h}$ on day 233 (second series; 20 frames in total). Collection of a frame took $\sim 15 \mathrm{~min}$. During the second series, severe thunderstorms forced interruption of the resistivity surveys on several occasions ( $1700 \mathrm{~h}$ on day 232 , and $0200 \mathrm{~h}$ and $0400-0600 \mathrm{~h}$ on day 233). All resistivity data were collected by manual switching with a Geopulse earth resistance meter (Campus Geophysical Instruments, UK), an instrument described in detail in Hubbard and others (1998).

Water pressure and electrical conductivity data were collected with an automated data logger at 10 min intervals in borehole $5(\mathrm{C})$ (the instrumentation is described in detail in Kulessa and others (2003a)). For consistency with common notation (Equation (2a)), all values of water conductivity are given in terms of water resistivity in the present study, being a measure of total concentration of dissolved solutes in subglacial water (e.g. Stone and others, 1993).

\section{DATA INVERSION AND RESULTS}

\subsection{Inversion concepts}

We have used the finite-difference code DCIP3D (Geophysical Inversion Facility, University of British Columbia, Canada; Li and Oldenburg, 2000) to invert our electrical resistivity data. Suffice to say here that the inversion process involves least-squares minimization of the misfit between a current resistivity model and a reference model. The current model is calculated from the field data together with the measurement errors. The reference model (Fig. 2) corresponds to a time-averaged, basal resistivity structure, using estimates of the resistivities of glacial ice $\left(10^{8} \Omega \mathrm{m}\right)$, subglacial sediments $\left(10^{3} \Omega \mathrm{m}\right)$ and crystalline bedrock $\left(10^{5} \Omega \mathrm{m}\right)$. The size of each cell in the finite-difference mesh used in the inversion process is illustrated in Figure 2 $\left(1.25 \times 1 \times 0.75 \mathrm{~m}^{3}\right)$, which places a lower limit on the spatial resolution in both the reference and current models. On completion of the iterative inversion process, the final current model is assumed to correspond as closely to the actual 3-D resistivity structure of the basal environment as can feasibly be reconstructed from the field data.

\subsection{Results}

Each measurement frame in either of the two series was inverted individually, resulting in a total of 483 -D models of basal resistivity structure. Comparison of these models reveals that temporal changes in resistivity occur only within the blocks corresponding to the subglacial sediment layer, whilst all other blocks remain largely unaffected. This is consistent with the expectation that daily hydrological changes should largely be confined to this layer. A representative inverted model, together with the borehole base locations, is illustrated in Figure 3. The bulk resistivities are lower in the western part $(<1000 \Omega \mathrm{m})$ than in the eastern part $(\sim 1000 \Omega \mathrm{m})$ of the model. This model represents the data frame collected at $1000 \mathrm{~h}$ on day 223, which was the time of lowest water resistivity in the hydrological cycle between days 222 and 223 (Fig. 4b). Both water pressure (Fig. 4a) and resistivity (Fig. 4b) were typically high during the day and low during the night.

To investigate time-lapse changes in bulk subglacial resistivities, the measurement frame illustrated in Figure 3 was subtracted from those collected at all other times. The difference data were then projected onto the horizontal plane, and 'trimmed' to focus on the area between the four borehole bases where measurement coverage was particularly high. Comparison of representative 2-D images (Fig. 5) with water resistivity (Fig. 4b) reveals a close 


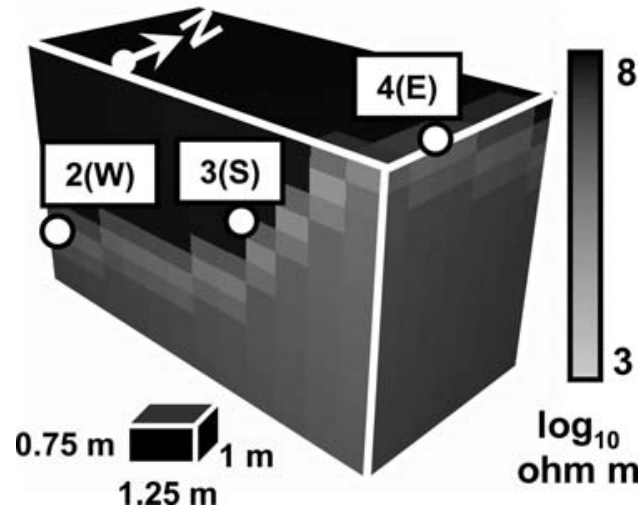

Fig. 2. The reference model and core finite-difference mesh used for 3-D inversion of the subglacial electrical resistivity data, corresponding to a volume section of the basal environment. Thick glacier ice with a resistivity of $10^{8} \Omega \mathrm{m}$ (black cells) is underlain by a thin layer of unlithified sediments $\left(10^{3} \Omega \mathrm{m}\right.$, shaded light grey) and thick crystalline bedrock $\left(10^{5} \Omega \mathrm{m}\right.$, shaded in darker grey). The dimensions of an isolated cell are shown for scale, and borehole base locations are illustrated for reference where possible. See Figure 1c for geometrical reference.

correspondence. Resistivities increase between 1300 and $1500 \mathrm{~h}$ on day 222 , then drop to a minimum around $1000 \mathrm{~h}$ on day 223 , and finally increase again through the afternoon of day 223.

\section{INTERPRETATION}

We aim to estimate the hydraulic conductivity and porosity of the subglacial sediments with distance from the subglacial channel using the inverted resistivity models and the measurements of water resistivity in borehole $5(\mathrm{C})$. This is achieved in two principal stages. First, the electrical formation factor $(F)$ with distance from the channel is determined from Equation (2a), using daily amplitudes of bulk resistivity $\left(\rho_{\text {bulk }}\right)$ calculated from the inverted models. Daily amplitudes of water resistivity $\left(\rho_{\text {water }}\right)$ with distance from the channel are approximated by an exponential decay, consistent with borehole water quality and self-potential measurements (Hubbard and others, 1995; Kulessa and others, 2003a). Second, sediment porosity and hydraulic conductivity with distance from the channel are estimated respectively by combining Equations (2b) and (5) and Equations (3) and (4). We account for increasing clay content $\left(\varphi_{\mathrm{c}}\right)$, increasing electrical cementation factor of clayey sediments $\left(m_{\mathrm{cs}}\right)$, and decreasing grain radius $(R)$ with distance from the channel, and consider standard errors incurred during each progressive step in the estimation procedure.

\subsection{Daily resistivity amplitudes and electrical formation factor}

Daily amplitudes of bulk resistivity were calculated for each cell in the inverted models using bulk resistivity maxima and minima measured between 1300 and $1200 \mathrm{~h}$ on successive days for both the first and second series (Fig. 6). During the first series (Fig. 6a), amplitudes are high to the west of borehole 5(C) and lower to the east of it. During the second series (Fig. 6b), amplitudes are high near boreholes 3(S), 5(C) and $1(\mathrm{~N})$, and decrease progressively away from this area. Assuming that the channel is marked by maximum daily

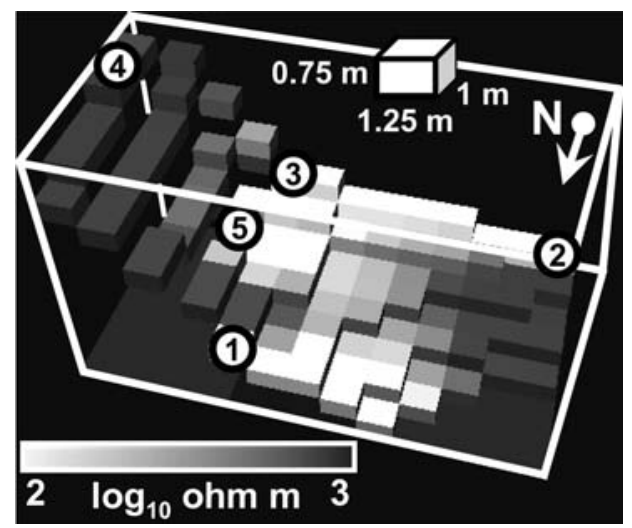

Fig. 3. The inverted reference resistivity frame recorded at $1000 \mathrm{~h}$ on day 223, 1996. Only the cells corresponding to the layer of unlithified subglacial sediments is shown, which slopes from the base of borehole $4(\mathrm{E})$ towards the bases of boreholes $3(\mathrm{~S})$ and $5(\mathrm{C})$, and then towards the bases of boreholes $2(\mathrm{~W})$ and $1(\mathrm{~N})$. The north arrow points down-glacier, and water flow is predominantly towards the observer. Note that the view is in the opposite direction compared to Figure 2 as dictated by basal topography. See Figure 1c for geometrical reference.

amplitudes of bulk resistivity, these observations are consistent with channel establishment between the two measurement periods, which agrees with previous inferences by Kulessa and others (2003a). Indeed, the locations of the highest daily amplitudes of bulk resistivity calculated for the second series agree approximately with the strike of the subglacial channel as inferred by Kulessa and others (2003a) (Fig. 6b), allowing for limited spatial resolution as determined by the size of model cells and some statistical variability in amplitudes along the channel (as explained below). Daily amplitudes of bulk resistivity were subsequently averaged using the cells located along the channel axis (Fig. 6), and likewise the averages of all cells located along 'virtual' axes parallel to the channel were calculated. The resulting, mean daily amplitudes of bulk resistivity are illustrated in Figure 7 together with standard errors. Standard errors decrease away from the channel up to a distance of $\sim 5 \mathrm{~m}$, then increase again. Comparison of Figures 6 and 7 reveals that the increase in standard error at distances of $>5 \mathrm{~m}$ from the channel is probably caused by a decrease in measurement coverage, and thus sensitivity in the inversion process. The same is true for the easternmost data point. Standard errors at the channel are probably high relative to adjacent data points because acquisition of any particular measurement frame took $\sim 15 \mathrm{~min}$, a period over which noticeable changes in water resistivity occurred in the channel, increasing uncertainty in the inversion process.

At the channel the electrical formation factor $(F)$ is readily calculated using Equation (2a) since both bulk and water resistivity are known. Here, $F$ has a value of $5.1 \pm 0.2$. The decrease in daily amplitudes of water resistivity with distance from the channel can be approximated by an exponential decay (Kulessa and others, 2003a). Equation (2a) suggests that daily amplitudes of bulk resistivity should therefore also decrease exponentially in the same direction, unless $F$ changes. Daily amplitudes of bulk resistivity close to the channel are fit well, in a leastsquares sense, by an exponential decay (Fig. 7). This implies that $F$ is approximately constant up to a distance of $\sim 2.5 \mathrm{~m}$ from the channel. At larger distances daily amplitudes of 

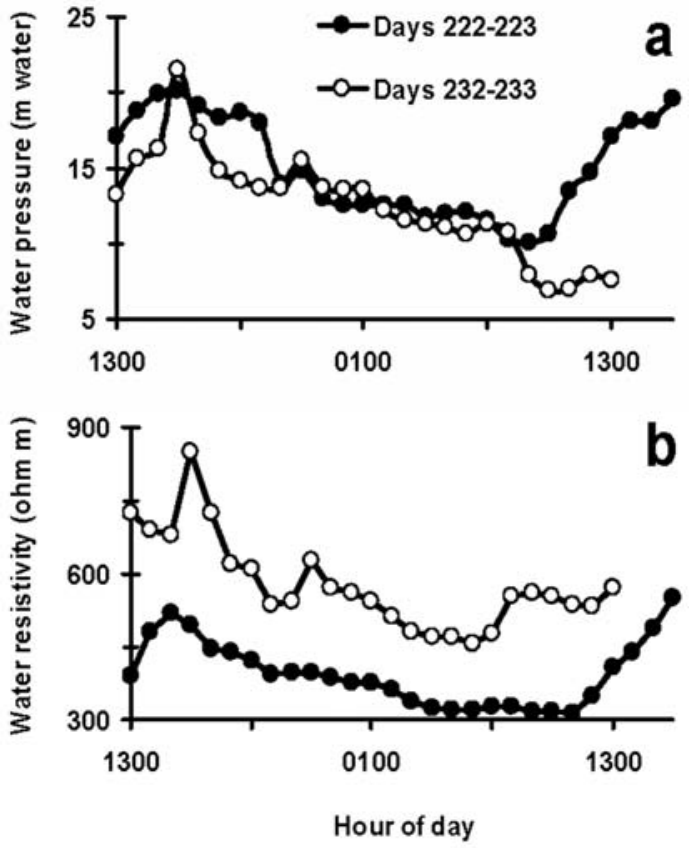

Fig. 4. Water-pressure (a) and water resistivity (b) data recorded in borehole 5(C) (see Fig. 1c for borehole locations) during both survey periods.

bulk resistivity lie consistently above the calculated exponential decay, implying that $F$ is higher at these distances than at the channel. We find that $F$ has values of $11.4 \pm 0.8$ at a distance of $5 \mathrm{~m}$ from the channel, and $37.0 \pm 16.0$ at the farthest distance of $8.75 \mathrm{~m}$ (Fig. 8a). We emphasize that values calculated for distances of $>5 \mathrm{~m}$ are subject to considerable uncertainty since measurement coverage is relatively poor (see above).

\subsection{Determination of sediment porosity and hydraulic conductivity}

Estimation of porosity is complicated by the fact that Equation (5) contains the cementation factor of clayey sediments $\left(m_{\mathrm{CS}}\right)$ and clay volume fraction $\left(\varphi_{\mathrm{c}}\right)$, both of which are uncertain and potentially change with distance from the channel. Similarly, estimation of hydraulic conductivity using Equations (3) and (4) requires knowledge of median grain radius $(R)$ and the cementation factor of clay-free sediments $\left(m_{\mathrm{s}}\right)$. Both parameters are uncertain, and additionally $R$ potentially changes with distance from the channel. Here, we select a best estimate together with a range of uncertainty for each parameter, based on parameter values and relevant associated information previously published in the literature. Best estimates and uncertainty ranges are summarized in Table 1 and were chosen using the following criteria:

The electrical formation factor is effectively constant up to a distance of $\sim 2.5 \mathrm{~m}$ from the channel (Fig. 8a), implying that sediment composition is probably also constant over this distance. It is therefore unlikely that the cementation factor of clayey sediments $\left(m_{\mathrm{cs}}\right)$, clay volume fraction $\left(\varphi_{\mathrm{c}}\right)$ and median grain radius $(R)$ change over this distance.

Water pressure typically decreases exponentially away from the channel and exerts a major control on removal
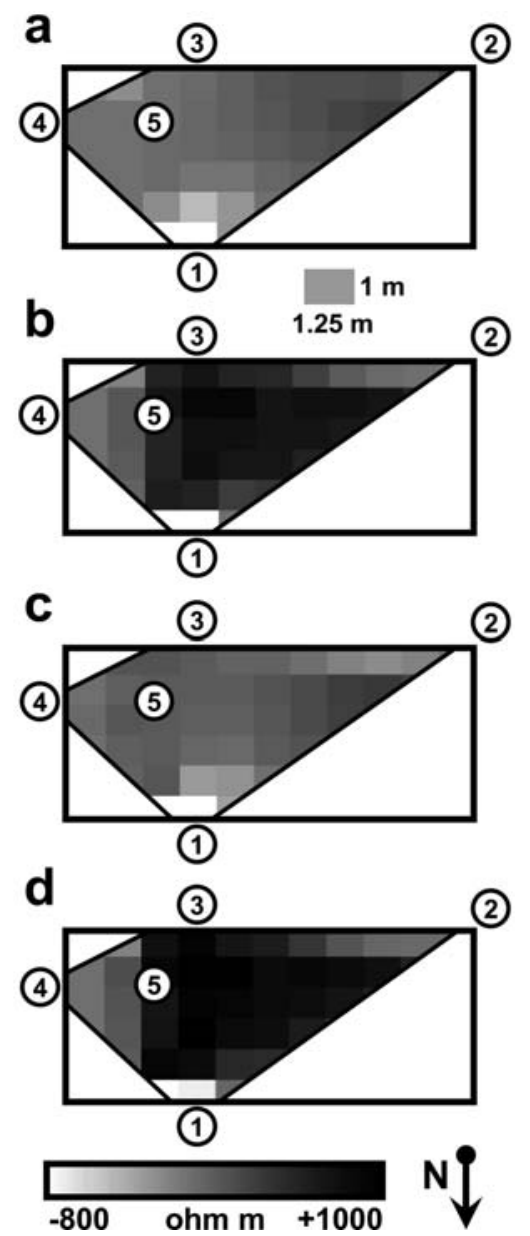

Fig. 5. Representative time-lapse resistivity difference images, projected onto the horizontal plane for convenient viewing. The dimensions of an isolated cell are shown for scale, and borehole base locations are shown for reference (see also Fig. 1c). The reference resistivity frame collected at $1000 \mathrm{~h}$ on day 223 (see Fig. 3) was subtracted from those collected at 1300 (a), 1500 (b) and $2100 \mathrm{~h}$ (c) on day 222, and at $1500 \mathrm{~h}$ on day 223 (d). Note that the images were trimmed from a rectangular shape to focus on the area of larger measurement coverage between the boreholes. Resistivity scale is different from Figures 2 and 3 because resistivity differences are shown, rather than absolute values.

of fine sediments (including clays) from the area near the channel (Hubbard and others, 1995). We therefore assume that clay volume fraction $\left(\varphi_{\mathrm{c}}\right)$ and the cementation factor of clayey sediments $\left(m_{\mathrm{CS}}\right)$ increase and median grain radius $(R)$ decreases exponentially at distances of $>2.5 \mathrm{~m}$ from the channel.

The cementation factor of clay-free sediments $\left(m_{\mathrm{s}}\right)$ typically has a value of $<1.5$ (Sharma, 1997) and likely of 1.4 (Biella and others, 1983) which we therefore adopt as our best estimate. Nonetheless, $m_{\mathrm{s}}$ could potentially be as low as 1.3 (Telford and others, 1990, p. 649) or potentially as high as 2 depending on the ratio of pore size to pore throat size (Revil and Cathles, 1999), which we therefore adopt as our range of uncertainty.

Seagren (1999) detected noticeable amounts of clay minerals in the subglacial water system during the present study period, although Kulessa and others (2003a) inferred that clay mineral content at a distance of $<2.5 \mathrm{~m}$ from the channel was very low. We choose 


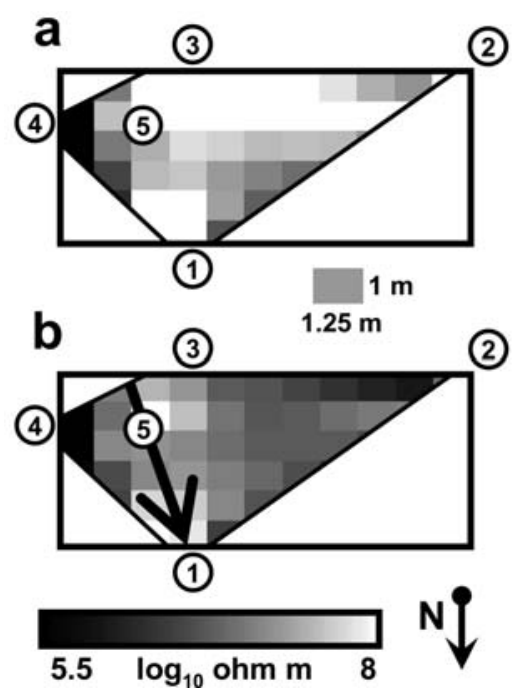

Fig. 6. Daily amplitudes of bulk resistivity for (a) the first (days 222223) and (b) the second (days 232-233) series of measurements, projected onto the horizontal plane for convenient viewing. The dimensions of an isolated cell are shown for scale, and borehole base locations are shown for reference (see also Fig. 1c). Note that the images were trimmed from a rectangular shape to focus on the area of larger measurement coverage between the boreholes. The black arrow in (b) indicates the direction of channelized water flow as inferred by Kulessa and others (2003a), which agrees approximately with the location of the highest daily amplitudes of bulk resistivity.

0.005 (equivalent to $0.5 \%$ of sediment volume) as the best estimate for clay volume fraction $\left(\varphi_{\mathrm{c}}\right)$ at the channel, but allow for the fact that it could potentially be up to twice as large or as low as 0.001 . We further choose $0.01-0.2$ as the range of clay volume fraction $\left(\varphi_{\mathrm{c}}\right)$ at a distance of $10 \mathrm{~m}$ from the channel, with a best estimate of 0.1 .

We expect clay volume fraction $\left(\varphi_{\mathrm{c}}\right)$ at the channel to be non-zero but nonetheless to be very small, and therefore assume that the cementation factor of clayey sediments $\left(m_{\mathrm{cs}}\right)$ is slightly higher than the cementation factor of clay-free sediments $\left(m_{\mathrm{s}}\right)$ at this location. We thus use $1.5-2.1$ as the range of uncertainty for $m_{\mathrm{CS}}$, with 1.5 as the best estimate near the channel. It is unlikely that sediments mixed with several per cent of clay, as assumed here for a distance of $10 \mathrm{~m}$ from the channel, have a cementation factor $\left(m_{\mathrm{CS}}\right)$ of less than 2.1 (Worthington, 1993; Revil and Cathles, 1999; Aristodemou and Thomas-Betts, 2000). Revil and Cathles (1999) found that sands mixed with $>50 \%$ kaolinite, illite or smectite can have respective cementation factors $\left(m_{\mathrm{cs}}\right)$ of up to $3.15, \sim 3.28$ and $\sim 4.17$. The sediments beneath Haut Glacier d'Arolla contained fractions of all three types of clay minerals during the melt season considered here (1996), although clay volume fraction $\left(\varphi_{c}\right)$ was much less than $50 \%$ (Seagren, 1999). We choose 2.1-3.0 as the range of uncertainty for $m_{\mathrm{Cs}}$ at a distance of $10 \mathrm{~m}$ from the channel, with a best estimate of 2.75.

Median grain radius $(R)$ of channel-marginal sediments was found to have a value of $\sim 1.75 \times 10^{-3} \mathrm{~m}$ (Hubbard and others, 1995). Replacing $10 \%$ of the volume of these sediments with clay minerals gives a value of $\sim 1.60 \times 10^{-3} \mathrm{~m}$ for $R$. Assuming that both values could

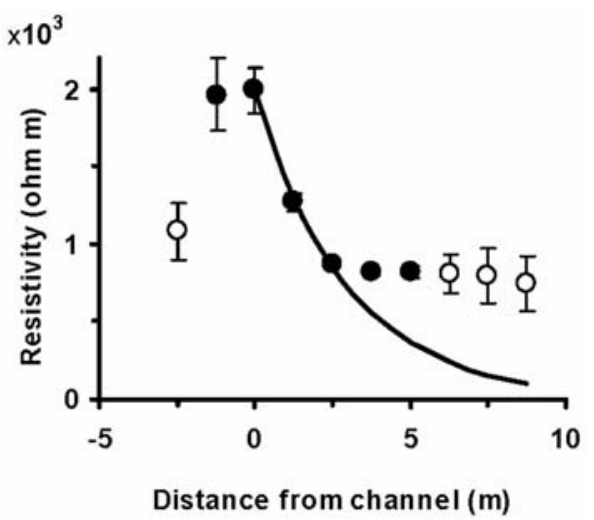

Fig. 7. Measured daily amplitudes of bulk resistivity (circles with error bars) and calculated exponential decay (solid line). Closed and open circles respectively represent data points of high and low confidence based on measurement coverage. See text for further explanation.

be subject to $100 \%$ error, we chose $0.88-3.50 \times 10^{-3} \mathrm{~m}$ and $0.81-3.25 \times 10^{-3} \mathrm{~m}$ as the ranges of uncertainty for $R$ at the channel and a distance of $10 \mathrm{~m}$ away from it, with respective best estimates of $1.75 \times 10^{-3} \mathrm{~m}$ and $1.60 \times 10^{-3} \mathrm{~m}$.

In either of these cases, worst scenarios are considered. Actual uncertainty was probably much less in most cases. Standard errors were calculated for porosity and hydraulic conductivity as each parameter is varied individually within the given range of uncertainty, all other parameters being kept constant at the respective best estimate. An overall standard error for porosity and hydraulic conductivity was subsequently calculated. Sediment porosity (Fig. 8b) was found to decrease from $0.34 \pm 0.01$ at the channel to $0.26 \pm 0.01$ at a distance of $5 \mathrm{~m}$ from it, and hydraulic conductivity (Fig. 8c) was calculated to decrease from $(6.4 \pm 2.1) \times 10^{-2} \mathrm{~m} \mathrm{~s}^{-1}$ to $(3.3 \pm 2.2) \times 10^{-2} \mathrm{~m} \mathrm{~s}^{-1}$ over the same distance. At distances of $>5 \mathrm{~m}$ from the channel, porosity was found to decrease further and hydraulic conductivity to increase again. However, confidence in these findings must be low as discussed above, and illustrated further by high standard errors in the case of hydraulic conductivity (Fig. 8c), in particular.

\subsection{Discussion}

The hydraulic conductivity of the unlithified sediments near the subglacial channel in our study area was previously estimated to have values of several $10^{-2} \mathrm{~m} \mathrm{~s}^{-1}$ depending on exact location, based on slug-test data collected in the 1995 summer melt season (Kulessa and others, 2005). An earlier hydraulic conductivity estimate by Hubbard and others (1995), based on reconstruction of diurnal water-pressure waves measured in the 1993 summer melt season, was smaller $\left(\sim 10^{-4} \mathrm{~m} \mathrm{~s}^{-1}\right)$. This discrepancy is explained by Kulessa and others (2005) in terms of progressive removal of fine sediments between 1993 and 1995 by channelinduced erosional processes, the existence of which was originally inferred by Hubbard and others (1995). Since the present study was conducted 1 year after the 1995 melt season, we assume that the slug-test derived hydraulic conductivity estimate of several $10^{-2} \mathrm{~m} \mathrm{~s}^{-1}$ may be more representative for the present (1996) subglacial hydraulic 

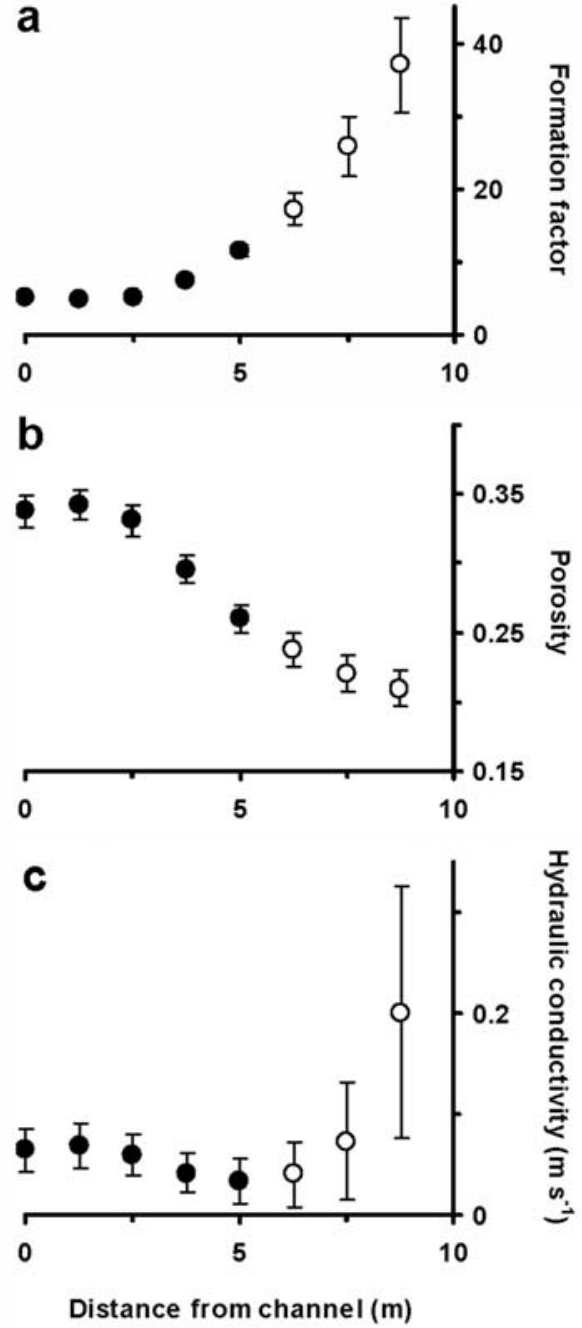

Fig. 8. Calculated values of electrical formation factor (a), porosity of clayey sediments $\left(\phi_{\mathrm{cs}}\right)$ (b) and hydraulic conductivity of clayey sediments $\left(K_{\mathrm{cs}}\right)(\mathrm{c})$ with distance from the channel. Closed and open circles respectively represent data points of high and low confidence based on measurement coverage. See text for further explanation.

conditions than that of Hubbard and others (1995). Indeed, we observe that the present estimates of hydraulic conductivity $\left((6.4 \pm 2.1) \times 10^{-2} \mathrm{~m} \mathrm{~s}^{-1}\right.$ decreasing to $(3.3 \pm 2.2) \times$ $10^{-2} \mathrm{~m} \mathrm{~s}^{-1}$ ) agree well with those inferred by Kulessa and others (2005).

In contrast to hydraulic conductivity, the porosity of the subglacial sediments in the present study area has so far not been known well. It is commonly assumed that sediment porosities of 0.3-0.4 may be typical for unlithified subglacial sediments (e.g. Fountain and Walder, 1998), although values as low as 0.2 have also been considered potentially realistic (e.g. Clarke, 1987). The present porosity estimates $(0.34 \pm 0.01$ decreasing to $0.26 \pm 0.01)$ thus lie well within the expected ranges.

The individual dependence of hydraulic conductivity and porosity on the four uncertain parameters involved in the electrical-hydraulic relationships is illustrated in Figure 9. The overall ranges of cementation factors $\left(m_{\mathrm{s}}, m_{\mathrm{cs}}\right)$, clay volume fraction $\left(\varphi_{\mathrm{cs}}\right)$ and median grain radius $(R)$ in Figure 9 are defined approximately by the maximum and minimum values for each parameter in Table 1, irrespective of distance
Table 1. Summary of best estimates, together with ranges of uncertainty, for the cementation factors of clayey and clay-free sediments $\left(m_{\mathrm{cs}}, m_{\mathrm{s}}\right)$, clay volume fraction $\left(\varphi_{\mathrm{c}}\right)$, and median grain radius $(R)$ with distance from the channel

\begin{tabular}{cccc}
\hline $\begin{array}{c}\text { Distance } \\
\text { from channel }\end{array}$ & $\begin{array}{c}\text { Cementation } \\
\text { factor of clayey } \\
\text { sediments* }\end{array}$ & $\begin{array}{c}\text { Clay volume } \\
\text { fraction }\end{array}$ & $\begin{array}{c}\text { Median grain } \\
\text { radius }\end{array}$ \\
$\mathrm{m}$ & $1.50_{-0.1}^{+0.6}$ & $0.005_{-0.004}^{+0.005}$ & $1.75_{-0.875}^{+3} \mathrm{~m}$ \\
\hline $0-2.5$ & $\begin{array}{c}\text { exponentially } \\
\text { increases to }\end{array}$ & $\begin{array}{c}\text { exponentially } \\
\text { increases to }\end{array}$ & $\begin{array}{c}\text { exponentially } \\
\text { increases to }\end{array}$ \\
& $2.75_{-0.65}^{+0.25}$ & $0.1_{-0.09}^{+0.1}$ & $1.6_{-0.8}^{+1.6}$ \\
\hline 10 & & &
\end{tabular}

*Cementation factor of clay-free sediments is assumed to range between 1.3 and 2, with a best estimate of 1.4.

from the channel. We emphasize that these overall ranges must therefore not be confused with individual ranges of uncertainty used for particular distances from the channel in the calculation of hydraulic parameters (Table 1). Hydraulic conductivity increases with cementation factor of clayey sediments $\left(m_{\mathrm{cs}}\right)$ and median grain radius $(R)$, and decreases with clay volume fraction $\left(\varphi_{\mathrm{cs}}\right)$ and cementation factor of clay-free sediments $\left(m_{\mathrm{s}}\right)$ (Fig. 9). Porosity increases with cementation factor of clayey sediments $\left(m_{\mathrm{cs}}\right)$ and decreases with clay volume fraction $\left(\varphi_{\mathrm{cs}}\right)$ (Fig. $9 \mathrm{a}$ and b). The dependence of both hydraulic conductivity and porosity on $m_{\mathrm{CS}}$ is particularly strong, and relatively minor in the case of $\varphi_{\text {cs }}$. The dependence of hydraulic conductivity on $R$ is also considerable, and strong for $m_{\mathrm{s}}<1.5$. Despite the marked dependence of hydraulic conductivity and porosity on several parameters and the fact that we have chosen worst-case scenarios in all cases when selecting individual ranges of parameter uncertainty in section 4.2 (Table 1), the resulting overall standard errors were found to be low (Fig. 8). In practice, it is important that at least constraints on median grain radius $(R)$ and clay volume fraction $\left(\varphi_{\mathrm{cs}}\right)$ are available. Knowledge of $\varphi_{\mathrm{cs}}$ can also guide the choice of a best estimate and a range of uncertainty for the cementation factor of clayey sediments $\left(m_{\mathrm{cs}}\right)$ together with values previously published in the literature (section 4.2).

In summary, our inferences suggest that hydraulic conductivity and porosity of unlithified subglacial sediments beneath Alpine glaciers can decrease noticeably over distances as small as a few metres away from subglacial channels. This implies that the speed of subglacial water flow towards or away from such channels probably changes on similar distance scales, which is likely also true for the ability of subglacial sediments to deform as their composition and hydraulic properties change.

\section{CONCLUSIONS}

We collected repeat electrical resistivity data at the bed of Haut Glacier d'Arolla and inverted the data in three dimensions using a reference model. The inverted resistivity models reflect the establishment of channelized subglacial drainage in the study area as inferred earlier by Kulessa and others (2003a). Inverted models were further used to 

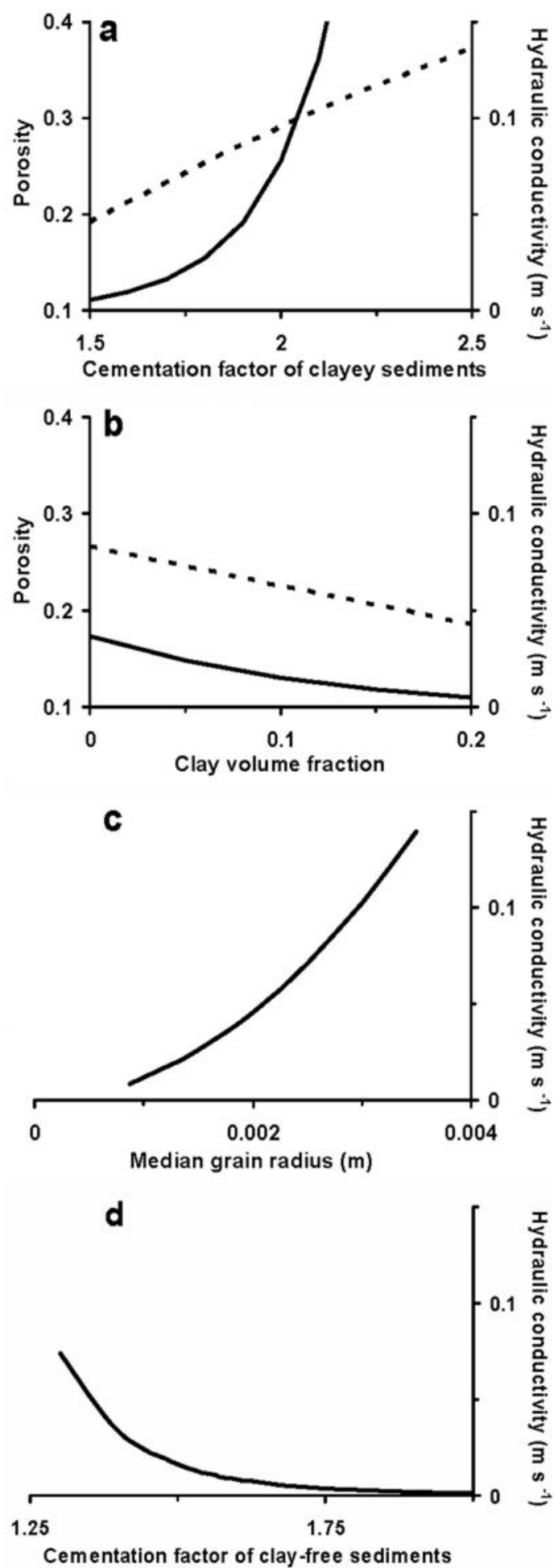

Fig. 9. Sensitivity of hydraulic conductivity ( $K_{\mathrm{cs}}$; solid lines and right ordinates) and porosity ( $\phi_{\mathrm{cs}}$; dashed lines and left ordinates) of clayey sediments to changes in: (a) cementation factor of clayey sediments $\left(m_{\mathrm{cs}}\right)$; (b) clay volume fraction $\left(\varphi_{\mathrm{c}}\right)$; (c) median grain radius $(R)$; and (d) cementation factor of clay-free sediments $\left(m_{\mathrm{s}}\right)$. Ordinate scale is the same in all plots for convenient comparison, although in (a) hydraulic conductivity reaches much higher values for $m_{\mathrm{cs}}>2.2$ than those shown on the ordinate.

estimate the hydraulic conductivity and porosity of the unlithified, clay-bearing subglacial sediments with distance from the channel, using theory developed by Revil and Cathles (1999). We estimate that hydraulic conductivity decreases from $(6.4 \pm 2.1) \times 10^{-2} \mathrm{~m} \mathrm{~s}^{-1}$ at the channel to
$(3.3 \pm 2.2) \times 10^{-2} \mathrm{~m} \mathrm{~s}^{-1}$ at a distance of $5 \mathrm{~m}$ from it, and that porosity decreases from $0.34 \pm 0.01$ to $0.26 \pm 0.01$ over the same distance. Such estimates are difficult to obtain by other means. Our findings thus suggest that both hydraulic conductivity and porosity of unlithified sediments can change noticeably over small distances in the vicinity of subglacial channels. This is likely to affect the speed of water flow towards and away from such channels as well as the rate of channel-marginal sediment deformation.

With regard to the main objectives of the present study (questions 1-3 in section 1), we therefore find that it is indeed possible to produce time-lapse images of 3-D bulk resistivity changes across the glacier bed, which are useful in identifying both subglacial hydraulic processes and properties. It is particularly encouraging that hydraulic conductivity and porosity estimates are subject to acceptable standard errors, despite the fact that worst-case scenarios were considered when choosing uncertainty ranges for the parameters governing the electrical-hydraulic relationships. These relationships can therefore be considered robust when at least constraints on uncertain parameters are available and measurement coverage is sufficient to inform the inversion process. We do, however, caution that inversion, and thus ultimately estimates of hydraulic processes and properties, can rapidly become unreliable when measurement density is insufficient. Careful planning of measurement coverage (e.g. through forward modelling) is therefore important. We recommend that planning of future subglacial resistivity surveys should consider (i) increased measurement coverage compared to that used in the present study, and (ii) sample extraction and determination of the governing parameters in the electrical-hydraulic relationships in the laboratory.

\section{ACKNOWLEDGEMENTS}

Fieldwork was conducted while B. Kulessa was in receipt of a University of Wales Postgraduate Studentship, which is gratefully acknowledged. We thank A. Binley for loan of the Geopulse electrical resistivity meter, the Geophysical Inversion Facility of the University of British Columbia for a free licence for the code DCIP3D, and J. Becker for invaluable help in the field. We also thank J. Walder (Scientific Editor), G.K.C. Clarke, A. Fountain, and T. Pfeffer for their insightful and detailed comments on the original version of the manuscript, which led to major improvements.

\section{REFERENCES}

Archie, G.E. 1942. The electrical resistivity $\log$ as an aid in determining some reservoir characteristics. Trans. AIME, 146, 54-64.

Aristodemou, E. and A. Thomas-Betts. 2000. DC resistivity and induced polarisation investigations at a waste disposal site and its environments. J. Appl. Geophys., 44(2), 275-302.

Biella, G., A. Lozej and I. Tabacco. 1983. Experimental study of some hydrogeophysical properties of unconsolidated porous media. Ground Water, 21(6), 741-751.

Binley, A., A. Ramirez and W. Daily. 1995. Regularised image reconstruction of noisy electrical resistance tomography data. In Beck, M.S., B.S. Hoyle, M.A. Morris and R.C. Waterfall, eds. Proceedings of the Fourth Workshop of the European Concerted Action on Process Tomography, April 6-8 1995, Bergen, Norway. Manchester, University of Manchester Institute of Science and Technology, 401-410. 
Blake, E.W. 1992. The deforming bed beneath a surge-type glacier: measurement of mechanical and electrical properties. $(\mathrm{PhD}$ thesis, University of British Columbia.)

Blake, E.W. and G.K.C. Clarke. 1999. Subglacial electrical phenomena. J. Geophys. Res., 104(B4), 7481-7495.

Brand, G., V. Pohjola and R.LeB. Hooke. 1987. Evidence for a till layer beneath Storglaciären, Sweden, based on electrical resistivity measurements. J. Glaciol., 33(115), 311-314.

Clarke, G.K.C. 1987. Subglacial till: a physical framework for its properties and processes. J. Geophys. Res., 92(B9), 9023-9036.

Copland, L., J. Harbor, M. Minner and M. Sharp. 1997. The use of borehole inclinometry in determining basal sliding and internal deformation at Haut Glacier d'Arolla, Switzerland. Ann. Glaciol., 24, 331-337.

Fischer, U.H. and G.K.C. Clarke. 2001. Review of subglacial hydromechanical coupling: Trapridge Glacier, Yukon Territory, Canada. Quat. Int., 86, 29-43.

Fountain, A.G. and J.S. Walder. 1998. Water flow through temperate glaciers. Rev. Geophys., 36(3), 299-328.

Freeze, R.A. and J.A. Cherry. 1979. Groundwater. Englewood Cliffs, NJ, Prentice Hall.

Gordon, S., M. Sharp, B. Hubbard, C. Smart, B. Ketterling and I. Willis. 1998. Seasonal reorganization of subglacial drainage inferred from measurements in boreholes. Hydrol. Process., 12(1), 105-133.

Haeberli, W. and W. Fisch. 1984. Electrical resistivity soundings of glacier beds: a test study on Grubengletscher, Wallis, Swiss Alps. J. Glaciol., 30(106), 373-376.

Harbor, J., M. Sharp, L. Copland, B. Hubbard, P. Nienow and D. Mair. 1997. The influence of subglacial drainage conditions on the velocity distribution within a glacier cross section. Geology [Boulder], 25(8), 739-742.

Hubbard, B. and P. Nienow. 1997. Alpine subglacial hydrology. Quat. Sci. Rev., 16(9), 939-955.

Hubbard, B.P., M.J. Sharp, I.C. Willis, M.K. Nielsen and C.C. Smart. 1995. Borehole water-level variations and the structure of the subglacial hydrological system of Haut Glacier d'Arolla, Valais, Switzerland. J. Glaciol., 41(139), 572-583.

Hubbard, B., A. Binley, L. Slater, R. Middleton and B. Kulessa. 1998. Inter-borehole electrical resistivity imaging of englacial drainage. J. Glaciol., 44(147), 429-434.

Iken, A., K. Fabri and M. Funk. 1996. Water storage and subglacial drainage conditions inferred from borehole measurements on Gornergletscher, Valais, Switzerland. J. Glaciol., 42(141), 233-248.
Kulessa, B. 2000. Geophysical borehole investigations of subglacial drainage conditions at Haut Glacier d'Arolla, Switzerland. (PhD thesis, University of Wales, Aberystwyth.)

Kulessa, B., B. Hubbard and G.H. Brown. 2003a. Cross-coupled flow modeling of coincident streaming and electrochemical potentials and application to subglacial self-potential data. J. Geophys. Res., 108(B8), 2381. (10.1029/2001JB001167.)

Kulessa, B., B. Hubbard, G.H. Brown and J. Becker. 2003b. Earth tide forcing of glacier drainage. Geophys. Res. Lett., 30(1), 1011. (10.1029/2002GL015303.)

Kulessa, B., B.P. Hubbard and G.H. Brown. 2005. Hydrogeological analysis of slug tests in glacier boreholes. J. Glaciol., 51(173), 269-280.

Li, Y. and D.W. Oldenburg. 2000. 3-D inversion of induced polarization data. Geophysics, 65(6), 1931-1945.

Marion, D., A. Nur, H. Yin and D. Han. 1992. Compressional velocity and porosity in sand-clay mixtures. Geophysics, 57(4), 554-563.

Mitchell, A., G.H. Brown and R. Fuge. 2001. Minor and trace element export from glacierized Alpine headwater catchment (Haut Glacier d'Arolla, Switzerland). Hydrol. Process., 15(18), 3499-3524.

Murray, T. 1997. Assessing the paradigm shift: deformable glacier beds. Quat. Sci. Rev., 16(9), 995-1016.

Revil, A. and L.M. Cathles. 1999. Permeability of shaly sands. Water Resour. Res., 35(3), 651-662.

Seagren, A.G. 1999. The nature of solute acquisition and suspended sediment dynamics in channelised subglacial weathering environments, Haut Glacier d'Arolla, Valais, Switzerland. (PhD thesis, University of Wales, Aberystwyth.)

Sharma, P.V. 1997. Environmental and engineering geophysics. Cambridge, Cambridge University Press.

Sharp, M.J. and 6 others. 1993. Geometry, bed topography and drainage system structure of the Haut Glacier d'Arolla, Switzerland. Earth Surf. Process. Landforms, 18(6), 557-571.

Smart, C.C. 1996. Statistical evaluation of glacier boreholes as indicators of basal drainage systems. Hydrol. Process., 10, 599-613.

Stone, D.B., G.K.C. Clarke and E.W. Blake. 1993. Subglacial measurement of turbidity and electrical conductivity. J. Glaciol., 39(132), 415-420.

Telford, W.M., L.P. Geldart and R.E. Sheriff. 1990. Applied geophysics. Second edition. Cambridge, etc., Cambridge University Press.

Worthington, P.L. 1993. The uses and abuses of the Archie equations, 1: The formation factor-porosity relationship. J. Appl. Geophys., 30(3), 215-228. 